\title{
Comparison of Pre-School Education Curricula of Turkish Republic of Northern Cyprus (TRNC), England, Finland, Southern Cyprus and India
}

\author{
Filiz Erbay* \\ Preschool Education Department, Near East University, Nikosia, Turkish Republic of \\ Northern Cyprus \\ ORCID: 0000-0002-9766-8570
}
Dervişe Amca Toklu
Preschool Education Department, Near East University, Nikosia, Turkish Republic of
Northern Cyprus
ORCID: 0000-0003-2336-1741

\author{
Şermin Kuset \\ Nikosia, Turkish Republic of Northern Cyprus \\ ORCID: 0000-0001-7629-631X
}

Hulin Sidd1k

Preschool Education Department, Near East University, Nikosia, Turkish Republic of

Northern Cyprus

ORCID: 0000-0002-4813-8493

\begin{tabular}{|c|c|}
\hline Article history & In this research, it is aimed to compare the preschool education curricula \\
\hline $\begin{array}{l}\text { Received: } \\
27.01 .2021\end{array}$ & $\begin{array}{l}\text { of Turkish Republic of Northern Cyprus (TRNC), England, Finland, } \\
\text { Southern Cyprus and India. In this study, pre-school education curricula }\end{array}$ \\
\hline $\begin{array}{l}\text { Received in revised form: } \\
16.02 .2021\end{array}$ & $\begin{array}{l}\text { in TRNC, England, Finland, Southern Cyprus and India were examined } \\
\text { and the age groups covered by the curricula, their general objectives, } \\
\text { areas of achievements, content and evaluation sections were compared. }\end{array}$ \\
\hline $\begin{array}{l}\text { Accepted: } \\
18.02 .2021\end{array}$ & $\begin{array}{l}\text { In the selection of the curricula of the countries included in the study, } \\
\text { easily accessible and convenient sampling was used and the curricula of }\end{array}$ \\
\hline Key words: & the countries whose full texts can be accessed on the internet were \\
\hline $\begin{array}{l}\text { Comparative education, } \\
\text { Pre-school curricula, } \\
\text { Early childhood period }\end{array}$ & $\begin{array}{l}\text { 1ncluded. The data were collected using the document analysis method } \\
\text { and the scanning model was used to determine the existing situation. The } \\
\text { data in the study were obtained by using descriptive analysis and content } \\
\text { analysis methods. When the findings of the research are examined, it is } \\
\text { stated that the TRNC preschool education program has limited the age } \\
\text { range, has aims and achievements to support all developmental areas, } \\
\text { deals with early literacy, mathematics and environmental awareness in } \\
\text { detail, is quite comprehensive in terms of content, it is also included in } \\
\text { the evaluation of the teacher. All these points are considered as strengths }\end{array}$ \\
\hline
\end{tabular}

*Correspondency: filizerbay42@gmail.com 
of the TRNC preschool education program. It has also been observed that there are features that need to be improved. The TRNC program does not include self-evaluation of the child, does not emphasize the communication and interaction of society-school-programme-child. Suggestions are provided at the end of the study in accordance with the research findings.

\section{Introduction}

Early childhood is a very critical period in terms of the child's maturation, growth and developmental progress (Erbay \& Durmuşoğlu Saltal1, 2020; Saygın, 2019; Slicker \& Hustedt, 2019). It is extremely important that the education of children, who are in such a critical and rapid development process, is supported by carefully prepared educational curricula withoutsparing any room for accidental occurrences. Educational curriculum is defined in different ways, but the point where they all converge is pertinent to definitions that include the permanent and beneficial use of the child's experiences. Educational curriculum can be defined as a comprehensive and multidimensional concept that includes all the experiences of the child inside and outside school (Zembat, Tunçeli, \& Akşin-Yavuz, 2019). The pre-school educational curriculum is an organized educational framework or structure that has general and specific goals and achievements, that includes activities through which the teacher tries to introduce these purposes to children during the day, and where learning takes place (Köksal, Balaban Dağal, \& Duman, 2016). The TRNC preschool educational curriculum is an up-to-date curriculum that was prepared by various experts from the field and started to be implemented in 2016. While curriculum aims to support the development of the child holistically, it is based on active teaching and learning approaches in line with a child-centered, flexible, eclectic, immersive, holistic, child-centered general understanding (MEB, 2016).

Research displays that high-quality applications and education curricula in early childhood period are directly related to the brain development and other development areas of the child, support preparation for schooling, and has a positive impact on the future school achievement of children (Culkin, 2000; MEB, 2013; Wesley \& Buysse, 2010). On the other hand, it is stated that low-quality early childhood period applications can cause permanent damage on the development of the child and give permanent material damage to the family and the society at large (Başaran \& Ulubey, 2018; Ruhm \& Waldfogel, 2011). A high-quality preschool education is directly related to the quality of the applied curriculum. For this reason, a high-quality education curriculum should target the entire development of preschool children and try to support the multi-faceted development. To that end, preschool years are the most important times for such experiences (Tuncer, 2015a).

Several studies continue to be carried out with various methods and techniques in order to increase the quality of pre-school education and curricula. Some of these studies are within the scope of comparative early childhood education. Comparative education is a discipline that helps define the similarities and differences of two or more education systems in different cultures and different countries, explains similar-looking phenomena, and offers useful suggestions about ways to educate people (Çubukçu, Yılmaz, \& İnci, 2016). With comparative education studies, educators can access information about how to find solutions to educational problems in other countries, how good practices are developed, and what alternative approaches can be in the education process (Ertuğrul, 2019; Kuru Çetin, Korkmaz, \& Öner, 2017; Tekgöz, 2017). In these studies, researchers wondered about the nature of educational practices and educational structures belonging to different cultures and wrote about the consequences of applying different educational practices in their respective countries (Bray, Adamson, \& 
Mason, 2014; Gülsoy Kerimoğlu, 2019; Ilgar \& İncedere, 2016; İş, 2017; Tanrısevdi \& Kıral, 2018; Y1lmaz Bodur, 2019; Wilson, 2003).

When the studies on the comparison of pre-school education curricula and education systems in the world and in the TRNC are examined, it can be seen that there are different studies using different samples (Aktan \& Akkutay, 2014; Durmuşçelebi \& Bilgili, 2014; İncikab1 \& Tuna, 2012; Kazu \&Yılmaz, 2018; Soydan, 2015; Y1ldırım, 2008). Koech (2003) compared the historical and socio-economic differences and similarities of early childhood education curricula of Kenya and the United States of America in his study. Burce (2013) examined how latent cultural beliefs were incorporated into pedagogy and practice in bicultural early childhood settings in New Zealand and Japan. Vallberg Roth (2014) compared the Scandinavian Early Childhood Education and Care curriculum with the countries of Finland, Iceland, Norway and Sweden in terms of content and quality. In his study, Kim (2016) examined the Korea Nuri Curriculum Document and the Australian Early Years Learning Framework in terms of socio-cultural comparison. Akyol, Tantekin Erden, and Altun (2014) comparatively examined pre-school education practices and transition from preschool to primary school in Shanghai, Korea, Finland, which achieved high success in the PISA 2009 exam, and Turkey. In Choi's (2013) study, it is seen that he examined and compared pre-school education curricula in Turkey and South Korea in three dimensions. Şimşek (2015) tried to determine the similarities and differences between the social policies and practices of the European Union members England and Finland in the field of preschool education by comparing them with the practices in Turkey. Tuncer (2015b) compared pre-school education curricula with proven effectiveness with the pre-school education curriculum implemented in Turkey. In the comparative education study of Yaya (2016), the functioning of the quality systems of early childhood education institutions in Turkey and the North Carolina of United States of America was compared. Kaymak Eren, Çakmak Teloğlu and İlhan (2017) compared the scope and content of early childhood education curricula in OECD countries with the Turkish Early Childhood Education. Karabulut and Temel (2018) compared Turkish and Japanese preschool education systems. It has been determined that Ertuğrul (2019) compared the preschool education curriculum applied in Turkey with the preschool education curricula applied in Russia and Finland in terms of structure, general purposes, achievement, content, educational status, assessment-evaluation and additional curricula.

Considering the TRNC literature, it is striking that the number of studies on the comparison of early childhood education curricula and education systems is limited. Ersan (2018) compared the education systems of pre-school institutions in Finland, Japan, Turkey and TRNC. It is seen that Manolova-Yalçın and Ayan (2020) comparatively examined the education and control systems in TRNC, Turkey and Sweden.

As it is seen, there is no other study comparing the preschool education curriculum of TRNC with the pre-school education curricula of different countries. Therefore, in order to determine the strengths and weaknesses of the TRNC preschool education curriculum, it is important to compare it with the pre-school education curricula of different countries. It is believed that the findings obtained from this research can contribute to the future curriculum renewal or development studies. In addition, it is thought that such a study will shed light on the comparative education studies to be carried out in the future, will benefit the development of the comparative education field, and guide researchers.

The aim of this research is to compare the pre-school curricula of TRNC, England, Finland, Southern Cyprus and India. In line with this general purpose, answers were sought to the 
following questions.

\section{Sub-objectives:}

(1) Which age groups do pre-school education curricula in TRNC, England, Finland, Southern Cyprus and India cover?

(2) What are the similarities and differences between the preschool education curricula of TRNC and England, Finland, Southern Cyprus and India in terms of general objectives?

(3) What are the similarities and differences between the preschool education curricula of TRNC and England, Finland, Southern Cyprus and India in terms of acquisition areas?

(4) What are the similarities and differences between the preschool education curricula of TRNC and England, Finland, Southern Cyprus and India in terms of content features?

(5) What are the similarities and differences between the preschool education curricula of TRNC and England, Finland, Southern Cyprus and India in terms of assessment processes?

\section{Method}

In this section, the research model, data collection tools, research material, data analysis and process steps are included.

\section{Research Model}

This study is a comparative educational science research conducted using systematic and scientific methods by examining the age groups addressed by the preschool education curricula, general objectives, acquisition areas, the content of the curriculum (themes and concepts) and evaluation sections of different countries. Similarities and differences are revealed based on common criteria in terms of certain variables in comparative surveys (Karasar, 2016). Horizontal approach was used in comparing the curricula. In the horizontal approach, all dimensions of education systems are handled one by one and all variables of a certain period are brought side by side and differences and similarities are tried to be determined (Ültanır, 2000). In this study, in accordance with the horizontal approach, all variables were brought side by side within the framework of the research questions of the Turkish Republic of Northern Cyprus, England, Finland, Southern Cyprus and India pre-school education curricula and it was tried to determine the similarities and differences between them. In the study, the surveying model was used to determine the existing situation. The data were collected using the document review method. In document analysis, when an educational phenomenon is tried to be explained in depth and within its own context, the document review method is used to collect the required data (Özkan, 2019).

Easily accessible or convenient sampling was used in the selection of the curricula of the countries included in the study. Easily accessible or convenient sampling is based on completely available, fast and easy-to-reach items (Baltac1, 2018). In this context, the early childhood education curricula of England, Finland, Southern Cyprus and India, which can be accessed completely on the internet, and the TRNC preschool education curriculum constituted the sample of the study.

\section{Data Collection Tools}

In the study, the current pre-school education curricula of the Turkish Republic of Northern Cyprus, England, Finland, Southern Cyprus and India were obtained from the 
Ministry of Education and related websites. Turkish Republic of Northern Cyprus Pre-School Education Curriculum (MEB, 2016), England Early Years Foundation Stage (EYFS, 2020), Finland Pre-School Education Basic Plan (Esiopetuksen Opetussuunnitelman Perusteet, 2014),

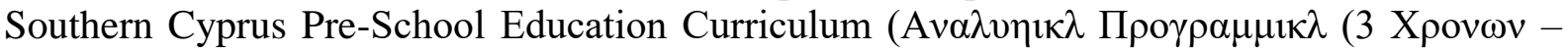

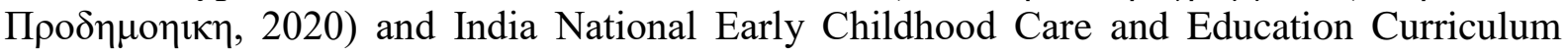
Framework (ECCE, 2005) were analyzed comparatively.

\section{Material of the Study}

The Turkish Republic of Northern Cyprus Preschool Education Curriculum (MEB; 2016) examined in the study consists of 50 pages and 8 main sections. These sections cover the rationale of the curriculum, the purpose of the pre-school education curriculum, curriculum outcomes, the characteristics of the preschool curriculum, learning areas (LA), Learning Outcomes (LO), planning and implementation, and evaluation. The England Early Years Basic Curriculum consists of 43 pages and 3 main sections: learning and development needs, assessment, protection and welfare requirements. The Finnish Pre-School Education curriculum consists of 69 pages and 5 main sections, namely the basics of the curriculum and the local curriculum, the general objectives of pre-school education, the formation of an environment that supports growth and learning, the principles of pre-school education, and the planning of supportive education for child development. The Southern Cyprus Pre-School Education curriculum consists of 154 pages and consists of 3 main sections, namely the basic pedagogical principles, areas of development, and cognitive objects sections. The Indian preschool curriculum consists of 85 pages and consists of 3 main sections. These sections are implementation details such as vision, logical and theoretical issues for an Indian child, details of goals for different development areas, and principles of the curriculum.

\section{Data Analysis Methods}

The data in the study were obtained by using descriptive analysis and content analysis methods. The main purpose in content analysis is to reach the concepts and relationships that can explain the collected data. Data summarized and interpreted in descriptive analysis are subjected to more in-depth processes in content analysis. The stages of content analysis are coding of data, finding themes, organizing and defining data according to codes, and interpreting the findings (Y1ldirım \& Şimşek, 2016). As a result of descriptive and content analysis, the similarities and differences between the curricula of the countries were revealed.

\section{Procedural Steps}

In this study, in line with the horizontal approach, the elements of the TRNC, England, Finland, Southern Cyprus and India curricula were handled one by one and brought side by side to identify differences and similarities. The documents collected within the scope of document review were examined in accordance with the document analysis stages such as accessing the documents, checking the originality of the documents, analyzing the data and using the data, and the obtained data were presented in a comparative manner (Yıldırım \& Şimşek, 2016).

- Reaching Documents: After the researchers determined the research subject, they reached the curricula of TRNC, England, Finland, Southern Cyprus and India.

- Checking the Authenticity of the Documents: The authenticity of the obtained documents was checked by sending them to researchers and teachers who worked on pre-school education in TRNC, England, Finland, Southern Cyprus and India. 
- Understanding the Documents: After the necessary checks of the documents, the stage of translation has started. Translation of pre-school curricula used in Finland and Southern Cyprus was analyzed together with translators whose mother tongue is Finnish and Greek and the second language is Turkish. The English translation curriculum of the pre-school curriculum used in India and the England curricula were analyzed together with translators whose mother tongue is English and the second language is Turkish. Researchers have personally participated in the stage in which these translations were carried out and tried to prevent errors arising from unique expressions used in pre-school education.

- Data Analysis: After the translation of the curriculum documents, the dimensions including the sub-objectives of the research were separated from the data obtained. The age groups, general objectives, achievements, content and evaluation categories covered by the curricula were created.

- Use of Data: Tables created during the comparison process were shown again to the implementers of TRNC, England, Finland, Southern Cyprus and India curricula, and they were asked whether there were any erroneous transfers during the interpretation process.

\section{Findings}

In this section, findings related to the general objective and sub-objectives of the study are provided. In this respect, Table 1 gives the findings as regards the question "Which age groups do pre-school education curricula in TRNC, England, Finland, Southern Cyprus and India cover?", which is the first sub-objective of the study.

Table 1. Age Groups Covered by TRNC, England, Finland, Southern Cyprus and India Preschool Education Curricula

\begin{tabular}{|c|c|c|c|c|c|}
\hline 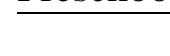 & TRNC & England & Finland & Southern Cyprus & India \\
\hline ge group & $3-6$ year & $2-5$ years of age & 6-7 years of age & $3-5$ years of age & $0-6$ years of age \\
\hline
\end{tabular}

When Table 1 is examined, it can be seen that TRNC pre-school education curriculum covers the education process of children aged 3-6, England curriculum covers 2-5 years of age, curriculum of Finland covers 6-7 years of age, curriculum of Southern Cyprus covers 3-5 years of age and curriculum of India covers 0-6 years of age.

As regards the second sub-objective of the study, "What are the similarities and differences between the preschool education curricula of TRNC and England, Finland, Southern Cyprus and India in terms of general objectives?", the findings are given in Table 3. 
Table 2. General Objectives of Pre-School Education Curricula of TRNC, England, Finland, Southern Cyprus and India

\begin{tabular}{|c|c|c|c|c|c|}
\hline & TRNC & England & Finland & Southern Cyprus & India \\
\hline $\begin{array}{l}\text { General Objectives } \\
\text { of the Curriculum }\end{array}$ & $\begin{array}{l}\text { can express himself / } \\
\text { herself and use } \\
\text { Turkish correctly, } \\
\text { beautifully and } \\
\text { effectively, } \\
\text { can lead a healthy life } \\
\text { in physical, mental } \\
\text { and social aspects, } \\
\text { have gained effective } \\
\text { communication } \\
\text { skills, } \\
\text { show sensitiveness } \\
\text { towards their natural, } \\
\text { social and historical } \\
\text { environment, } \\
\text { are aware of their } \\
\text { responsibilities as } \\
\text { regards themselves } \\
\text { and their } \\
\text { environment, } \\
\text { have developed fair } \\
\text { approaches in their } \\
\text { relations with people } \\
\text { which are distant } \\
\text { from discrimination, } \\
\text { have developed } \\
\text { awareness as regards } \\
\text { values of the culture } \\
\text { they are living in. }\end{array}$ & $\begin{array}{l}\text { To ensure that } \\
\text { children have the } \\
\text { knowledge and skills } \\
\text { they need to start } \\
\text { schooling, } \\
\text { eTo ensure full } \\
\text { learning among } \\
\text { children by providing } \\
\text { quality and } \\
\text { consistency in } \\
\text { childhood education } \\
\text { environments, } \\
\text { To ensure cooperation } \\
\text { among stakeholders, } \\
\text { To ensure that every } \\
\text { child is included and } \\
\text { supported, taking into } \\
\text { account equality of } \\
\text { opportunity and an } \\
\text { anti-discrimination } \\
\text { practices. }\end{array}$ & $\begin{array}{l}\text { To create positive } \\
\text { learning environments } \\
\text { by applying multi- } \\
\text { faceted activities based } \\
\text { on games, activities and } \\
\text { art, } \\
\text { To ensure permanent } \\
\text { interaction between } \\
\text { children and educators, } \\
\text { To promote gender } \\
\text { equality, developing the } \\
\text { capacity to understand } \\
\text { and respect the general } \\
\text { cultural heritage and the } \\
\text { religious and cultural } \\
\text { background of each } \\
\text { child, } \\
\text { To develop children's } \\
\text { cooperation and } \\
\text { interaction skills, } \\
\text { To raise individuals who } \\
\text { are respectful to other } \\
\text { people and to develop a } \\
\text { sense of social } \\
\text { belonging, } \\
\text { To ensure that balanced } \\
\text { communication between } \\
\text { the child and his parents } \\
\text { is preserved and } \\
\text { maintained, } \\
\text { assessment process. }\end{array}$ & $\begin{array}{l}\text { respected and to } \\
\text { respect, and who } \\
\text { want to develop } \\
\text { open relationships } \\
\text { with others, } \\
\text { To show how to be } \\
\text { creative and have the } \\
\text { ability to solve } \\
\text { problems on their } \\
\text { own, while ensuring } \\
\text { that the child has } \\
\text { several experiences, } \\
\text { To plan the } \\
\text { emergence of } \\
\text { emerging skills } \\
\text { (current) and } \\
\text { potential abilities } \\
\text { with the child by } \\
\text { using his / her pre- } \\
\text { existing (past) } \\
\text { experiences, } \\
\text { To emphasize the } \\
\text { importance of pre- } \\
\text { school education by } \\
\text { shaping children in } \\
\text { cooperation and } \\
\text { participation as a } \\
\text { curriculum for the } \\
\text { future. } \\
\end{array}$ & $\begin{array}{l}\text { To facilitate the } \\
\text { optimum } \\
\text { development of } \\
\text { children, } \\
\text { To establish the } \\
\text { foundation of the } \\
\text { child's full potential } \\
\text { and comprehensive } \\
\text { development and } \\
\text { lifelong learning. } \\
\text { To emphasize that } \\
\text { the partnership } \\
\text { between the } \\
\text { community and } \\
\text { ECCE centers is } \\
\text { important to the } \\
\text { well-being of the } \\
\text { people, while the } \\
\text { parents and home } \\
\text { have the main } \\
\text { eresponsibility for } \\
\text { the well-being of } \\
\text { the child. }\end{array}$ \\
\hline
\end{tabular}

When the general objectives of the preschool education curricula of TRNC, England, Finland, Southern Cyprus and India given in Table 2 are examined, it is seen that there are similarities and differences between the objectives. Considering the objectives similar to those of the TRNC 
curriculum, it is understood that the main objectives of the compared countries agree on supporting the development of children's personalities. Supporting all development areas in the curricula of other countries, except for Southern Cyprus, emerges as a common feature. The inclusion of cultural awareness, anti-discrimination and equality-related objectives in the TRNC curriculum in the England and Finland curricula can be considered as another common goal.

It has been noticed that the aim of improving the standards of teachers in the UK curriculum (addressed as first-year practitioners in the curriculum) is not included in the purpose statements of other countries' curricula, including the TRNC. In addition, by referring to the educational environments in the England and Finland curricula, the objectives of the quality and consistency of education environments and creating a positive learning environment were determined. However, it has been identified that these objectives are not included in the TRNC, Southern Cyprus or Indian curricula.

It is understood that the similar objectives of the TRNC and Finland curricula are to ensure equality in education for children. When the TRNC and India curricula were examined, no similar feature was encountered except supporting the personality and development of children.

Ensuring that children speak Turkish correctly and beautifully, which is among the general objectives of the TRNC curriculum, reveals its difference from other curricula. In addition, it can be said that the Finnish pre-school education curriculum includes more comprehensive objectives than other curricula. Strengthening the child-educator interaction, supporting the child-parent interaction and enabling the child to make self-evaluation are the goals that are not included in the general objective statements of the TRNC curriculum. Apart from this, another issue that is not emphasized as an objective statement in the TRNC curriculum but emphasized in the other curricula is the collaboration between stakeholders. Cooperation of all stakeholders in the environment of the child is included as a separate objective statement in the curricula of England, Southern Cyprus and India, and strengthening the interaction of child-parent-educator is highlighted in the Finnish curriculum as a separate objective statement.

Findings regarding the question "What are the similarities and differences between the preschool education curricula of TRNC and England, Finland, Southern Cyprus and India in terms of acquisition areas?" are given in Table 3. 
Table 3. Acquisition / Learning Areas of Preschool Education Curricula in TRNC, England, Finland, Southern Cyprus and India

\begin{tabular}{|c|c|c|c|c|c|}
\hline & TRNC & England & Finland & $\begin{array}{l}\text { Southern } \\
\text { Cyprus }\end{array}$ & India \\
\hline \multirow[t]{22}{*}{$\begin{array}{l}\text { Acquisition } \\
\text { areas of } \\
\text { curriculum }\end{array}$} & $\begin{array}{l}\text { Health and } \\
\text { Physical } \\
\text { Development }\end{array}$ & $\begin{array}{l}\text { Communication } \\
\text { and Language } \\
\text { Development }\end{array}$ & $\begin{array}{l}\text { Language and } \\
\text { Interaction } \\
\text { Acquisitions }\end{array}$ & $\begin{array}{l}\text { Personal and } \\
\text { Social } \\
\text { Consciousness }\end{array}$ & $\begin{array}{l}\text { Physical health, } \\
\text { Motor, Sensory } \\
\text { and }\end{array}$ \\
\hline & Learning Area & Physical & Mathematics & Emotional & $\begin{array}{l}\text { Perceptual } \\
\text { Enhancement, }\end{array}$ \\
\hline & Language, & Development & Field & Empowerment & \\
\hline & Communication & & Acquisitions & & Cognitive \\
\hline & $\begin{array}{l}\text { and Literacy } \\
\text { Preparation }\end{array}$ & $\begin{array}{l}\text { Personal, social } \\
\text { and emotional }\end{array}$ & Physical and & $\begin{array}{l}\text { Mobility } \\
\text { Capabilities }\end{array}$ & Development, \\
\hline & Learning Area & development & Motor & & Language \\
\hline & & & Development & Mental & Development, \\
\hline & Mathematics and & Literacy & Field & Strengthening & \\
\hline & $\begin{array}{l}\text { Logical Thinking } \\
\text { Learning Area }\end{array}$ & Mathematics & Acquisitions & & $\begin{array}{l}\text { Personal and } \\
\text { Socio- }\end{array}$ \\
\hline & $\begin{array}{l}\text { Science, Nature } \\
\text { and }\end{array}$ & $\begin{array}{l}\text { Understanding } \\
\text { the world }\end{array}$ & $\begin{array}{l}\text { Musical Field } \\
\text { Acquisitions }\end{array}$ & & $\begin{array}{l}\text { Emotional } \\
\text { Enhancement }\end{array}$ \\
\hline & Environmental & Expressive & Health & & Creative \\
\hline & Awareness & and design & Development & & Aesthetic \\
\hline & Learning Area & & Field & & Discretion \\
\hline & & & Acquisitions & & \\
\hline & $\begin{array}{l}\text { Personal Social } \\
\text { and Emotional }\end{array}$ & & Artistic & & \\
\hline & Development & & Acquisitions & & \\
\hline & Learning Area & & & & \\
\hline & & & Environmental & & \\
\hline & Creative and & & and Nature & & \\
\hline & Aesthetic & & Studies $\quad$ Field & & \\
\hline & Development & & Acquisitions & & \\
\hline & Learning Area & & & & \\
\hline
\end{tabular}

As can be seen in Table 3, diversity has been observed in the acquisition areas of the TRNC, England, Finland, Southern Cyprus and India. In the acquisition areas of the TRNC education curriculum, health and physical development learning area, language, communication and literacy preparation learning area, mathematics and logical thinking learning area, science, nature and environmental awareness learning area, personal social and emotional development area, creative and aesthetic development learning area fields are included. In the acquisition areas of the England preschool curriculum, on the other hand, communication and language development, physical development, personal, social and emotional development, literacy, mathematics, understanding the world, impressive arts and design are included. In the acquisition areas of the Finnish preschool education curriculum, language and interaction field acquisitions, mathematics field acquisitions, physical and motor development field acquisitions, musical field acquisitions, health development field acquisitions, artistic field acquisitions, environment and nature field studies acquisitions are included. Acquisition areas of the Southern Cyprus preschool curriculum include personal and social awareness, emotional empowerment, mobility skills and mental empowerment acquisitions. Finally, in the acquisition areas of the Indian preschool curriculum, physical, health, motor, sensory and perceptual development, cognitive development, language development, personal and socio-emotional development, creative and aesthetic appreciation acquisitions are included.

In the TRNC curriculum, it has been observed that the acquisition areas of almost all countries are referred to under separate titles. However, it was observed that the musical field included in the Finnish curriculum was not handled as a separate title in the TRNC curriculum. Although 
there are learning outcomes related to this field in the TRNC curriculum, it is not addressed as an acquisition and learning area in a separate fashion. It is remarkable that in the TRNC curriculum, the acquisition area related to science, nature and environment is considered as a separate area only in Finland. The creative and aesthetic development area in the curriculum acquisition areas of all countries, including the TRNC, is not included in the Southern Cyprus curriculum. When considered from these perspectives, it can be said that the TRNC acquisition areas are handled in a wide range and are comprehensive.

Findings regarding the question "What are the similarities and differences between the preschool education curricula of TRNC and England, Finland, Southern Cyprus and India in terms of content features?" are given in the Table 4.

Table 4. Content Features of the TRNC, England, Finland, Southern Cyprus and India Preschool Education Curricula

\begin{tabular}{|c|c|c|c|c|c|}
\hline & TRNC & England & Finland & Southern Cyprus & India \\
\hline $\begin{array}{l}\text { Content Features } \\
\text { the Curriculum }\end{array}$ & $\begin{array}{l}\text { of Size } \\
\text { Quantity } \\
\text { Time } \\
\text { Place } \\
\text { Direction } \\
\text { Sense } \\
\text { Contrasts } \\
\text { Feelings } \\
\text { Color } \\
\text { Figure } \\
\text { Number }\end{array}$ & $\begin{array}{l}\text { Mathematics } \\
\text { Area-Measure } \\
\text { World } \\
\text { Art } \\
\text { Design } \\
\text { Color } \\
\text { Texture T } \\
\text { Music } \\
\text { Emotions }\end{array}$ & $\begin{array}{c}\text { Shape-Space perception } \\
\text { Location in space } \\
\text { Time perception } \\
\text { Measuring } \\
\text { Music } \\
\text { Handicrafts } \\
\text { hnologyPicture } \\
\text { Drama } \\
\text { Dance }\end{array}$ & $\begin{array}{l}\text { Language education } \\
\text { Visual arts } \\
\text { Social Studies } \\
\text { Social and Politic } \\
\text { Content } \\
\text { Financial Content } \\
\text { Historical Content } \\
\text { Geographical Content } \\
\text { Religious and Ethic } \\
\text { Content Mus } \\
\text { Mathematics Education } \\
\text { Physical education } \\
\text { Natural Sciences }\end{array}$ & $\begin{array}{l}\text { Identity and } \\
\text { relationships: me, my } \\
\text { family and society } \\
\text { alMaintaining well-being: } \\
\text { Food, body, health, } \\
\text { hygiene and cleanliness, } \\
\text { security } \\
\text { Nature: plants, animals, } \\
\text { lbirds, fruits and vegetables } \\
\text { Physical environment: } \\
\text { cair, water, soil, universe } \\
\text { and seasons } \\
\text { Social environment: My } \\
\text { country, festivals and } \\
\text { celebrations, } \\
\text { neighborhood, } \\
\text { transportation. }\end{array}$ \\
\hline
\end{tabular}

As seen in Table 4, when the concepts discussed in the content of the TRNC preschool education curriculum are examined, it is seen that there are similarities and differences between countries. The biggest difference is between the Indian and TRNC curricula. It is noteworthy that the curriculum in India is a theme-centered curriculum whereas that the curricula of the TRNC and other countries are not thematic, and that these countries include concepts and different content in their curricula.

That being said, it has been determined that the time and direction concepts in the TRNC curriculum are not included in the England curriculum, whereas the world, design, technology and music content in the England are not included in the TRNC curriculum, and the other content dimensions are similar.

Including the concepts of time, place, direction, location in place, measurement and quantity ,in the curricula of the TRNC and Finland, are the first striking similar points. However, it can be argued that the content of the Finnish curriculum is handled with a wider perspective. It is seen that content such as dance, drama, music, art, painting included in the Finnish curriculum are included in the TRNC curriculum as activities. The Finnish preschool curriculum is one which allows children to identify the content they want to learn and are curious about.

It is seen that the concepts in the TRNC curriculum are not included in the Southern Cyprus curriculum, and that content areas are included instead. The fact that social and political content, financial content, historical content, geographical content, religious and ethical content are not included in the TRNC curriculum can be considered as the differences between the curricula of 
the two countries.

Findings regarding the question "What are the similarities and differences between the preschool education curricula of TRNC and England, Finland, Southern Cyprus and India in terms of assessment processes?" are shown in Table 5.

Table 5. Evaluation Stages of Preschool Education Curricula of TRNC, England, Finland,

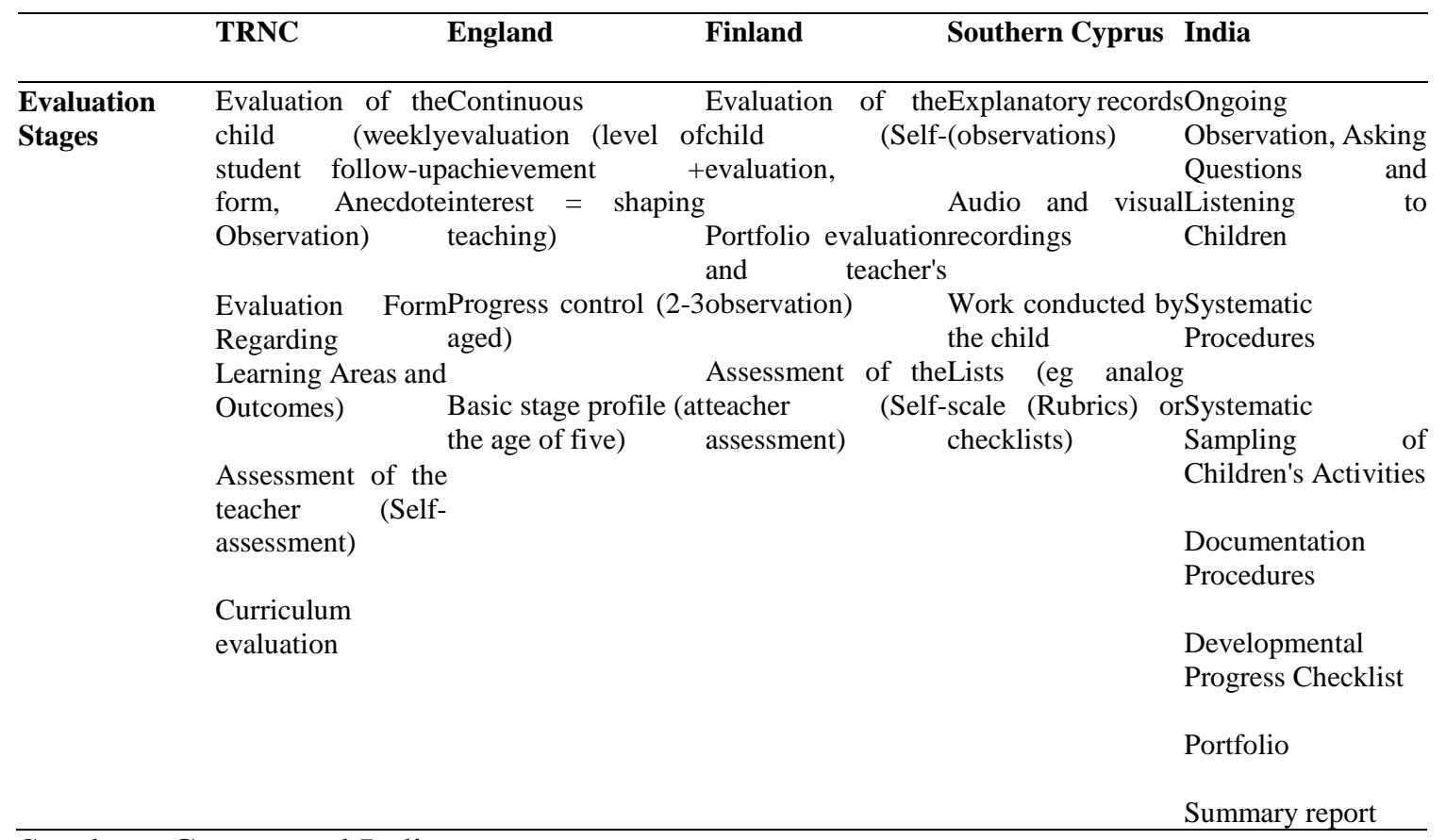

\section{Southern Cyprus and India}

When Table 5 is examined, it is seen that the evaluation of the teacher is included in the evaluation of the pre-school education curricula of TRNC, England, Finland, Southern Cyprus and India. This is the evaluation element that the TRNC and other countries are most closely similar. However, in the Finnish pre-school education curriculum, the child's self-evaluation is also included in the evaluation of the child besides the teacher evaluation. With this dimension, it differs from the TRNC curriculum.

While the TRNC preschool curriculum provides an opportunity for the evaluation of the child, teacher and curriculum, only the evaluation of the child appears as a difference in the preschool education curricula of England, Southern Cyprus and India.

Another difference between the TRNC preschool curriculum and the pre-school curricula of other countries is related to the evaluation of the curriculum. While the evaluation of the curriculum is included in the TRNC, there is no such evaluation in other countries.

While the TRNC education curriculum includes evaluation of the child, weekly student monitoring form, anecdotal observation, and evaluation forums regarding learning areas and outcomes, the England education curriculum provides continuous evaluation, progress control and basic stage profile evaluations. In Finland, it is seen that child evaluation, self-evaluation, portfolio evaluation and teacher's observations are included. Explanatory records, audio and visual recordings, work conducted by the child and checklists are included in the education curriculum of Southern Cyprus. It is understood that on-going observation, asking questions 
and listening to children, systematic procedures, systematic sampling of children's activities, documentation procedures, developmental progress, checklist, portfolio and summary report evaluations are included in the Indian education curriculum.

\section{Conclusion and Recommendations}

This research has been studied to compare the TRNC preschool curriculum with the pre-school curricula of various countries. Pre-primary education curricula in England, Finland, Southern Cyprus and India are the curricula of which full texts are accessible. Therefore, the pre-school curricula of the TRNC, England, Finland, Southern Cyprus and India, which were determined with an easily accessible and convenient sampling method, constituted the sample of the study. In the study, the aim was to reveal the similarities and differences between the age group covered by the curriculum of each of these countries, the general objectives of the curriculum, the areas of acquisition, the content features, and the evaluation processes.

When the research findings were examined, it was revealed that pre-school education curricula were prepared to cover different age ranges. The TRNC curriculum covers the ages of 3-6, the England curriculum covers the ages of 2-5, the Finnish curriculum covers the ages of 6-7, the Southern Cyprus curriculum covers the ages of 3-5 and the Indian curriculum covers the ages of 0-6. It has been observed that there are limitations in the age ranges that the curricula address with the exception of India. This limitation is considered to be a positive feature in terms of curricula. In the preschool period, children are in a rapid development process in terms of all development areas (Özdemir, 2019; Simsar \& Kadim, 2017). Therefore, as their age progresses, they also progress developmentally. For example, the developmental characteristics of a 2-yearold child and a 6-year-old child differ from each other. Therefore, the educational needs that will support the development of children will also differ in this period. Limiting the curriculum that will serve these differences in terms of age and development will contribute to a better education in line with the current development of children. In this direction, it is believed that the TRNC preschool education curriculum has a positive feature.

When the findings regarding the second sub-objective of the study were examined, it was revealed that the common feature of the curricula of all countries in general is to support the development of children. It is observed that this is an Especially emphasized issue considered important as a desired feature in the content of TRNC curriculum. However, although the school-family cooperation is mentioned in different parts of the curriculum, the fact that the general objectives of the TRNC curriculum do not emphasize the cooperation and interaction of child-parent-school-educator-community stakeholders shows that a general purpose seen in other curricula is not included as a purpose statement in the TRNC curriculum. Including the interaction and participation of all stakeholders in an education curriculum and paying attention to developing cooperation between stakeholders is a feature that will contribute not only to the pre-school education curriculum, but also to education curricula at all levels. Education curricula implemented by pre-school education institutions should include all stakeholders affecting the learning process of the child within the framework of children, adults, and schools (Zembat, et al., 2019). In this respect, it can be said that the mentioned cooperation and interaction's not being included in the objective statements of the curriculum is a dimension that needs improvement.

When the results of the third sub-objective of the study were evaluated, it was observed that the acquisition areas included in the TRNC preschool education curriculum were to cover all development areas. This is a positive feature of the curriculum. In harmony with the aim of 
supporting all kinds of development areas included in the general-purpose statements, all development areas are also included as acquisitions. Considering that all developmental areas of the child are interrelated and that progress in one developmental area will contribute to other developmental areas, this situation will also contribute to the education process of the child (Özdemir, 2019). Another strength of the TRNC curriculum can be considered as including more detailed acquisition areas related to mathematics and literacy, which are found in the curricula of England and Finland, and environmental awareness which is included in Finnish curriculum. In general, it has been concluded that the acquisition areas included in the TRNC curriculum are comprehensively handled and prepared.

In light of the findings of the $4^{\text {th }}$ sub-problem of the research, it was concluded that the TRNC curriculum and the curricula of India and Southern Cyprus differ completely. The Indian curriculum is theme-centered whereas the TRNC curriculum includes concepts instead of themes. In the Southern Cyprus curriculum, different content areas such as social and political content, financial content, historical content, geographical content, and religious and ethical content are included. Themes and different content areas are used as tools in the realization of acquisitions in the TRNC preschool curriculum. In this respect, it can be said that the TRNC curriculum is more comprehensive than the Indian and Southern Cyprus curricula. The fact that it also includes time and direction concepts that are not included in the England curriculum updated in 2020 is considered to be another strength of the TRNC curriculum. However, it has been observed that the world, design, technology and music content in the England curriculum are not included in the TRNC curriculum. These elements can be considered as the dimensions of the TRNC curriculum that need improvement. Also, the inclusion of content such as dance, drama, music, art, and painting in the Finnish curriculum as activities used in the learning process is a positive feature of the TRNC curriculum.

Another result of the research is related to the evaluation processes of the curriculum. The practice of evaluating the teacher as well as the child in the TRNC curriculum is not available in the England, Southern Cyprus and India pre-school education curricula. The teacher is among the important elements of the curriculum. Evaluating the teacher's planning and implementation skills will also enrich that curriculum. For this reason, it can be said that the TRNC curriculum has a strong and important feature since it includes the evaluation of the teacher. Similarly, while evaluation of the curriculum is included in the TRNC curriculum, it is not included in the curricula of other countries which provide for the evaluation of the child merely. As a matter of fact, all countries prefer different methods of evaluating the child. However, it is an important detail that the Finnish curriculum includes the self-evaluation of the child which is not included in the evaluation process of the TRNC or other countries. Among the qualifications sought in a preschool curriculum is ensuring that the child recognizes and accepts himself / herself through the experiences to be acquired (Köksal et al., 2016). Through self-assessment, children discover what they know, what they can do and how they learn. In this discovery process, they have the opportunity to use high-level thinking skills from a critical perspective. It is ensured that they make sense of themselves objectively. Children become aware of their learning problems by recognizing their strengths and weaknesses. They can produce solutions to their own learning problems by using the detailed information they have acquired about their own learning paths (Gürlen, Boztunç-Öztürk, \& Eminoğlu, 2019). Children should be taught ways of selfevaluation so that the child can recognize himself, and this dimension should be included in pre-school education curricula. The work conducted by children and their own experiences are part of the documentation and evaluation in Finland where children are encouraged to perform self-assessment. It is ensured that children identify the areas they think are successful and identify the areas they want to learn again so that they can know themselves better. Self- 
assessment skills that develop gradually in the learning process are part of the learning path (Ertuğrul, 2019). Lähde (2018) states that in Finland, it is important for children to make choices in different areas in the preschool period, and in this context, children are given the opportunity to make certain choices and carry out self-evaluation. Zeng (2016) states that the evaluation step of preschool education in Finland is versatile, including self-assessment, which is one of the features that contribute to the quality of preschool education.

Within the framework of these results, the following recommendations can be developed:

In the future curriculum development and revision studies, a process related to the child's selfassessment can be included in the TRNC curriculum. The fact that technology-related content, which are among the $21^{\text {st }}$ century skills, are not only included in the acquisitions section in the TRNC curriculum, but also in the content and concepts section, can contribute positively to the curriculum. Objective statements that support child-family-teacher-school and community communication and cooperation can be included in the curriculum. By adding to the TRNC preschool curriculum new areas and sections for children with different languages and cultures, it can be ensured that pre-school teachers implement the curriculum by taking into account the characteristics of the children in their classes in an inclusive and equitable manner.

In future studies, the TRNC preschool education curriculum can be examined by comparing it with the curricula of different countries. Only acquisitions or only assessment processes can be evaluated to obtain more detailed results during reviews. Comparisons of curricula can be handled in line with the opinions of teachers, parents and experts. One of the limitations of this research is that it lacks a comparison regarding the learning process, which is an element of the education curriculum. In this sense, it is recommended to examine the differences and similarities related to the learning process in the comparative studies to be carried out on the TRNC preschool education curriculum.

\section{References}

Aktan, O., \& Akkutay, Ü. (2014). Pre-school education in the OECD countries and Turkey. Asian Journal of Instruction, 2 (1), 64-79.

Akyol, H., Tantekin Erden, F., \& Altun, D. (2014). Comparative examination of pre-school education practices and transition to primary school in Shanghai, Korea and Finland. In International Congress of Transition Between Levels and New Models in Education since the Foundation of the Republic to Today Proceedings Book (2014 January), 105-143. Antalya: Atatürk Research Center.

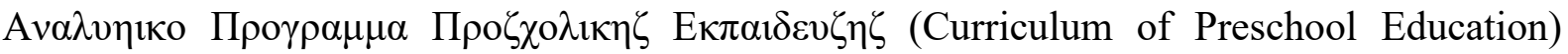

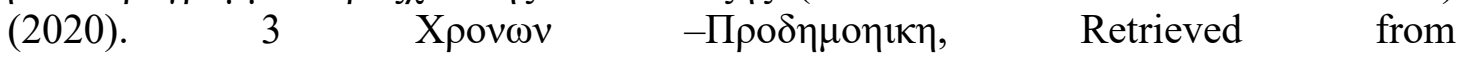
http://prod.schools.ac.cy/index.php/el/prodimotiki-ekpaidefsi/analytiko- curriculumma

Baltac1, A. (2018). A conceptual review on sampling methods and sample size problem in qualitative research. Bitlis Eren University Journal of Social Sciences Institute, 7(1), 231-274.

Başaran, S., \& Ulubey, Ö. (2018). Evaluation of 2013 Preschool Education Curriculum. Ankara University Faculty of Educational Sciences Journal, 51 (2), 1-38.

Bray, M., Adamson, B., \& Mason, M. (Eds.) (2014). Comparative education research: Approaches and methods (Vol. 19). Springer.

Burce, R. S. (2013). Bodies in context: a comparative study of early childhood education in New Zealand and Japan. (Unpublished Master Thesis). Massey University, Albany, New Zealand. 
Choi, J. (2013). Examination of preschool education in Turkey and South Korea. (Unpublished Doctoral Thesis) Marmara University, Institute of Educational Sciences, Istanbul.

Culkin, M. L. (2000). Managing quality in young children's curricula: the leader's role. New York: Teachers College Press.

Çubukçu, Z., Yılmaz, B. Y., \& İnci, T. (2016). Karşılaştırmalı Eğitim Programları Araştırma Eğilimlerinin Belirlenmesi - Bir İçerik Analizi. (Identifying research trends in comparative education curricula - a content analysis). Uluslararası Türkçe Edebiyat Kültür Ĕgitim Dergisi (International Journal of Turkish Literature Culture Education), 5 (1), 446-468.

Durmuşçelebi, M., \& Bilgili, A. (2014). The new (12-year) education system, the problems encountered and some of the applications in the world. Electronic Turkish Studies, 9 (2), 603-621.

ECCE, (2005). National Early Childhood Care and Education Curriculum Framework. Retrieved from https://wcd.nic.in/sites/default/files/national_ecce_curr_framework_ final_03022014\% 20\%28 2\%29.pdf

EFYS, (2020). Early Years Foundation Stage. Retrieved from https://assets.publishing.service.gov.uk/government/uploads/system/uploads/attachme nt_data/ file/896810/EYFS_Early_Adopter_Framework.pdf

Erbay, F., \& Durmuşoğlu Saltal1, N. (2020). Social independence as a predictor of preschool children's school readiness. OPUS - International Journal of Society Research, 16 (31), 4138- 4155. DOI: 10.26466 / opus.681864.

Ersan, F. (2018). Comparative study of pre-school education systems in Finland, Japan, Turkey and the Turkish Republic of Northern Cyprus. (Unpublished master's thesis). Near East University, Nicosia.

Ertuğrul, Ş. (2019). Comparison of pre-school education curricula: Turkey, Russia and Finland. (Unpublished master's thesis). Zonguldak Bülent Ecevit University, Zonguldak.

Esiopetuksen Opetussuunnitelman Perusteet. (Basics of the Preschool Curriculum). (2014). Retrieved from https://www.oph.fi/sites/default/files/documents/esiopetuksen_ opetussuunnitelman_perusteet_2014.pdf

Gülsoy Kerimoğlu, P. N. (2019). Comparative study of Turkish and South Korean education systems. (Unpublished master's thesis). Hacettepe University, Ankara.

Gürlen, E., Boztunç-Öztürk, N., \& Eminoğlu, E. (2019). An Investigation of Reliability Regarding Teacher, Self and Peer Evaluations at Primary School Level with Generalizability Theory. Journal of Measurement and Evaluation in Education and Psychology, 10 (4), 406-421.

Ilgar, R., \& İncedere, L. (2016). Comparative analysis of Turkish and Bulgarian education systems in terms of schooling. Journal of Black Sea Studies, 51, 51-74.

İncikab1, L., \& Tuna, A. (2012). Comparison of Turkish and American education systems in terms of preschool mathematics education curriculum developed for 60-72 months old. Mersin University Journal of Education Faculty, 8 (3), 94-101.

İş, E. (2017). Comparison of Turkish education system and Finnish education system preschool education and teacher training and appointment policies. Artuklu Human and Social Science Journal, 2 (1), 60-70.

Karabulut, R., \& Temel, F. Z. (2018). Comparison of Turkish and Japanese pre-school education systems. INES. Retrieved from https://www.academia.edu/38209994.

Karasar, N. (2016). Bilimsel Araştırma Yöntemi: Kavramlar, Ilkeler ve Teknikler (Scientific Research Method: Concepts, Principles and Techniques) (Second Edition). Nobel Publishing, Ankara. 
Kaymak Eren, S., Çakmak Teloğlu, Ş. K., \& İlhan, T. (2017). An international look at early childhood education in Turkey: the OECD report card. Uşak University, Journal of Social Sciences / UUSBD, 10 (2), 125-149.

Kazu, İ. Y., \& Yilmaz, M. (2018). Comparison of pre-school education in our country with OECD and EU member countries in terms of some data. Turkish Journal of Educational Studies, 5 (2), 64-75. DOI: 10.33907 / turkjes.404695.

Kim, S. (2016). A comparative study of early childhood curriculum documents focused on education for sustainability in South Korea and Australia. (Unpublished Master Thesis). Queensland University, Australia.

Koech, P.K. (2003). A comparative analysis of early childhood education in Kenya and the United States of America: Kenya's social and economic constraints. (Unpublished Master Thesis). University of Northern Iowa, USA.

Köksal, O., Balaban Dağal, A., \& Duman, A. (2016). Determination of pre-school teachers' views on pre-school education curriculum. The Journal of Academic Social Science Studies, 46, 379-394.

Kuru Çetin, S., Korkmaz, S. P., \& Öner, N. S. (2017). Examining the studies conducted in the field of comparative education in 15 years in terms of different variables. Adnan Menderes University Faculty of Education Journal of Educational Sciences, 8 (2), 2840.

Lähde, R. (2018). Esiopetuksen laadunarviointi lapsen ja vanhemman osallisuuden näkökulmasta. (Unpublished Master Thesis). University of Applied Sciences, Finland.

Manolova Yalçın, O., \& Ayan, M. (2020). Comparison of education and educational supervision systems of the Turkish Republic of Northern Cyprus (TRNC), Turkey and Sweden. Journal of Education and Instructional Research, 9 (1), 12-26.

Ministry of National Education. (MEB) (2013). T.C. Ministry of National Education, preschool education curriculum. Retrieved from http://www.meb.gov.tr/

Ministry of National Education. (MEB) (2016). T.R.N.C. Ministry of National Education, preschool education curriculum. Retrieved from http://talimterbiye.mebnet.net/ Ogretim\%20Curriculumlari/2018- 2019/okuloncesi2018.pdf address.

Özdemir, M. (2019). Investigation of the Relationship between Development Levels of 0-6 Years Old Children and Their Mothers' Traumatic Experiences and Family Life Quality. (Unpublished Master's Thesis). Hacettepe University, Ankara.

Özkan, U. B. (2019). Eğitim bilimleri araştırmalart için doküman inceleme yöntemi (Document review method for educational science research) (1 ${ }^{\text {st }}$ Edition). Ankara: Pegem Academy.

Ruhm, C. J., \& Waldfogel, J. (2011). Long-Term Effects of Early Childhood Care and Education (Institute for the Study of Labor (IZA): DP No. 6149). Bonn: IZA. Retrieved from http://ftp.iza.org/dp6149.pdf

Saygın, Y. (2019). Gelişim (Development). H. G. Ogelman (Ed.) Erken Çocukluk Döneminde Gelişim (Development in Early Childhood Period) (p.33-56) Ankara: Eğiten Book.

Simsar, A., \& Kadim, M. (2017). Preschool teachers' use of information technologies and its effect on teaching. Journal of Social Sciences, 7 (14), 127-146.

Slicker, G., \& Hustedt, J. T. (2019). Children's school readiness in socioeconomically diverse pre-K classrooms. Early Child Development and Care, 190 (15), 2366- 2379.

Soydan, S. (2015). Examining the opinions of teachers working in Turkey, America and Austria on pre-school geography education. Dumlupinar University Journal of Social Sciences, 40.

Şimşek, İ. (2015). Practices for pre-school education in terms of social policy: UK, Finland and Turkey examples. (Unpublished Master's thesis). Yalova University, Yalova. 
Tanrisevdi, F., \& Kiral, B. (2018). Comparison of Chinese and Turkish education systems. Journal of Contemporary Management Sciences, 5 (3), 223-240.

Tekgöz, M. (2017). Comparative educational analysis of the German state of BadenWüttemberg primary school curriculum and the Turkish primary school curriculum. (Unpublished master's thesis). Çukurova University Institute of Social Sciences, Adana.

Tuncer, B. (2015b). Examination of pre-school education curricula and comparison with the curriculum implemented in Turkey. International Journal of Field Education, 1 (2), 3958.

Tuncer, B. (2015a). Examination of contemporary approaches in preschool education and comparison with MEB preschool curriculum. International Journal of Field Education, -IJOFE, 1 (2), 39-58.

Ültanır, G. (2000). Karşılaştırmalı eğitim bilimi kuram ve teknikler (Comparative educational science theories and techniques). Ankara: Eylül Publishing.

Vallberg Roth, A. C. (2014). Nordic comparative analysis of guide lines for quality and content in early childhood education. Tidsskrift for Nordisk Barnehage for skning, 8(1), 1- 35.

Wesley, P. W., \& Buysse, V. (2010). The quest for quality: Promising innovations for early childhood curricula. Baltimore: Paul H. Brookes Pub. Co. What is a family child care home? (March 2005). Retrieved from http://ncchildcare.nc.gov/PDF_forms/ basic_info_FCCC_providers.pdf

Wilson, D. N. (2003). The future of comparative and international education in a globalised world. in comparative education (pp. 15-33). Dordrecht: Springer.

Yaya, D. (2016). Quality practices in early childhood education: a comparison between systems. (Unpublished doctoral dissertation). Hacettepe University, Ankara.

Yıldırım, M. (2008). Preschool education in European Union countries \& Turkey. Electronic Journal of Social Sciences, 7 (25), 91-110.

Yıldırım, A., \& Şimşek, H. (2016). Sosyal bilimlerde nitel araştırma yöntemleri (Qualitative research methods in social sciences) (10th edition). Ankara: Seçkin Publishing.

Y1lmaz Bodur, Z. (2019). A comparative analysis of gifted education in Turkey and Singapore. Necatibey Faculty of Education Electronic Journal of Science and Mathematics Education, 13 (2), 1166-1185. Doi: 10.17522/Balikesirnef.633470.

Zembat, R., Tunçeli, H. İ., \& Akşin-Yavuz, E. (2019). Erken Çocuklukta Eğitim Programları ve Uygulamalar (Early Childhood Education Curricula \& Applications). Ankara: Memories Publishing,

Zeng, B. (2016). Study on the model of preschool education in Finland, Asian Social Science, 12(10), 163-166. 